\title{
Proceeding
}

Supplementary Issue: Summer Conferences of Sports Science. Costa Blanca Sports Science Events, 20-21 September 2019. Alicante, Spain.

\section{Relationship between human development index and the sport results of Brazilian swimming athletes}

\author{
RAFAEL GOMES-SENTONE ${ }^{1} \triangle$, JOSE FRANCISCO LOPEZ-GIL², CRISTIANO ISRAEL CAETANO ${ }^{1}$, \\ FERNANDO RENATO CAVICHIOLL ${ }^{1}$ \\ ${ }^{1}$ Federal University of Paraná State, Curitiiba, Paraná, Brazil \\ 2Physical Education Department, Murcia University, Murcia, Spain
}

\begin{abstract}
The identification of sports talents has been scientifically studied exploring epidemiological factors as predictors of success. Seeking to advance research of this nature, the present study aims to identify the relationship between the human development index (HDI) and the sports outcome of Brazilian swimming athletes. Method: the ranking of the Brazilian Water Sports Confederation between 2013-2017 was used for all age categories and swimming events from 1 st to 100th place. The city where the athletes train was divided into categories according to the HDI being very high (1), high (2), medium (3), low (4) and very low (5), and the HDI in four indexes: general, income, longevity and education. Descriptive statistics were made for the number of cities and athletes according to the HDI. The assumption of normality was verified by the Kolmogorov-Smirnov test. To find correlations between variables, the Spearman Rho test for nonparametric variables was used to find the chance of having sports performance as a function of the HDI. 12271 athletes, 5230 women and 7041 men in 192 cities were identified. There was a positive correlation for overall HDI, income and education for men and women ( $p<.00)$; not so for longevity. Results: higher chances of having a sports athlete in swimming were found in cities with very high overall $\mathrm{HDI}(\mathrm{OR}=2.83 ; 95 \% \mathrm{Cl}=1.95-4.11)$, demonstrating 6.2 times more likely to have swimming athletes in HDI income city. Conclusion: The overall $\mathrm{HDI}$, income and education were relevant social indicators in identifying athletes with sports performance. Keywords: Athletic performance; Censuses; Social factors; Economics factors.

Cite this article as:

Gomes-Sentone, R., Lopez-Gil, J.F., Caetano, C.I., \& Cavichiolli, F.R. (2019). Relationship between human development index and the sport results of Brazilian swimming athletes. Journal of Human Sport and Exercise, 14(5proc), S2009-S2018. doi:https://doi.org/10.14198/jhse.2019.14.Proc5.22

Corresponding author. Federal University of Paraná State, Curitiiba, Paraná, Brazil. https://orcid.org/0000-0003-4289-8990

E-mail: sentoneforest@hotmail.com

Supplementary Issue: Summer Conferences of Sports Science. Costa Blanca Sports Science Events, 20-21 September 2019. Alicante, Spain.

JOURNAL OF HUMAN SPORT \& EXERCISE ISSN 1988-5202

(C) Faculty of Education. University of Alicante

doi:10.14198/jhse.2019.14.Proc5.22
\end{abstract}




\section{INTRODUCTION}

The search for parameters to demonstrate the level of development of a Nation regarding its competitive sports it's a research that possess a wide and fertile academic field. Studies of that nature intend to identify which factors are responsible for the existence of from a specific country with better odds of reaching world competitions than other countries. (De Bosscher et al., 2015; Houlihan \& Green, 2005).

From many of the studied factors, were explored, the size of the cities were the athletes train (Baker et al. 2009; Fraser-Thomas, Cote \& MacDonald, 2010), the athletes birth quartile (Baker \& Logan, 2007; Bruner et al., 2011; Hancock, Adler \& Cote 2013; Lidor et al., 2014; Finnegan et al., 2016; Gomez-Lopez, Sanchez, Gallegos \& Rios, 2017; Ortiz \& Colomina, 2019), quantity of sports centres (McGowin, 2010; Rossing, Nielsen, Elbe \& Karbing, 2016), financial resources (Farinola, Tunon, Laino, Marchesich \& Rodriguez, 2018), public policies that incentive sports (De Bosscher et al., 2015; Canan, Santos \& Starepravo, 2017), place of birth (Cote, MacDonald, Baker \& Abernethly, 2006; Baker \& Logan, 2007; Bruner, MacDonald, Pickett \& Cote, 2011; Lidor et al., 2014; Fimnnmegan, Richardson, Littlewood \& Mcardlea, 2016) and population density (Hancok, Coutinho, Cote, \& Mesquita, 2017; Caetano, Sentone, López-Gil, Caetano \& Cavichiolli, 2020).

Hancock, Coutinho, Cote, \& Mesquita (2017) found that Portuguese volleyball players have more than double of the chances of becoming professional players if there are born in cities with 200 to 399 thousand habitants, at the same time that Costa, Cardoso and Gargante (2013) verified that Brazilian soccer players possess bigger changes of becoming professional athletes if they are born in cities with less than 100 thousand habitants. However, Bruner et al. (2011) verified that Ice Hockey players from Finland and Sweden originates from cities with less than 30 thousand habitants, in contrast with Canadian and USA hockey players coming from communities with 100 to 500 thousand habitants. Even different sports within the same country demonstrate a deviation regarding the preponderance of successful athletes, as it was verified by FraserThomsa, Cote and MacDonald (2010) for swimming Canadian athletes, that are more susceptible to development in smaller communities.

Baker et al. (2009) sought to deplete this research strand by noting that the ideal size for the cities to produce Olympic athletes are of 10.000 - 29.999 in United Kingdom, 250.000-499.999 in the USA, 1,000,0002,499,999 in Canada, and 2,500,000-4,999,999 in Germany, suggesting once more that the local effects are influenced by factors such as the sport specialty, social culture and geography.

Coakley (2015) point out that the study of sports is integrated with education, economical and political spheres, as such the research should take into consideration, besides the athletes gender, race and abilities, the social class that influence how the sport is organized, therefore, the social development element became a fundamental predictor of a society's activities, like the sport. In fact, Houlihan e Green (2005) noted that each country is differently influenced by each factor, due to the country's own global development.

According to the United Nations (UN), the global development of a nation is measured by the Human Development Index (HDI) in three dimensions: income, education, and health, being one of the tools utilized in more than 170 countries since the 90s (PNUD, 2019). Following the data from 2017 (UNDP, 2018), Brazils $\mathrm{HDI}$ is 0,759 (79 from 189 countries). Although it shows deviancies within the education system, Brazils HDI is considered to be high in human development, as the country have shown good economical and social results within the past years. 
Researches such as of Gonzales et al. (2018) noted that countries with a high HDI indicates a population with higher levels of physical activities, as were the research of Chacon-Araya, Villarreal-Angeles \& MoncadaJimenez (2018) and Santos et al. (2019) who identified positive associations within a small group of Costa Rica athletes and the professional athletics ranks of high $\mathrm{HDI}$ and sports performance.

There was a positive association between HDI and prevalence of physical inactivity. Less developed countries showed the lowest prevalence of physical inactivity, while physical inactivity was more prevalent among the most developed countries (Dumith et al., 2011) and the relationship between children's healthrelated quality of life and their movement behaviours is moderated by their country's human development index. This should be considered when 24/h movement behaviour guidelines are developed for children around the world (Dumuid et al., 2018).

In light of the HDI being a universal and perennial evaluation mechanism, as well as diverging between demographic factors in predicting the sports performance, the current research has the objective of identify the correlation between the human development index (HDI) and the sportive result of the Brazilian swimming athletes.

\section{MATERIAL AND METHODS}

\section{Participants}

The participants were Brazilian elite swimmers. The sex and living city of swimmers from all categories were provided by the Brazilian Confederation of Aquatic Sports (CBDA) through a database between 2013 and 2017. The database included 113,820 competition results, with 12,271 swimmers, 7,039 (57.3\%) male and $5,232(42.6 \%)$ female, ranged from 9 to 63 years old divided in 11 age categories. We selected all athletes who had enough performance to be classified in the Brazilian ranking, which is unique from 1 to 100 . We assume that the place where athletes live is the same where they train - a standard practice in the literature that studies the effects of the place of birth (Côtè et al., 2006). Due to the large number of athletes and the variety of ages and rankings, we disregarded whether the athlete had a high or low competitive level because there was no tool that could neither categorize nor prove it. Finally, the present research was submitted and approved by the Ethics Committee of the Health Sciences Sector of the Federal University of Paraná $\mathrm{n}$. 2405344.

\section{Measures}

It was used the 2015 Brazilian census information, the most updated one, once Brazil is a country with great territorial extension and population size. The 2015 census provided the figures of people living in each of the 5,570 Brazilian cities, and in each of the 27 states, all legally registered as independent entities. The smallest city in this study has 2,707 inhabitants and the largest has 11,253,503 inhabitants.

According to the utilized HDI division by index we have the category 1 - higher human development (usually reach countries and well developed), category 2 - high human development (usually countries in a fast growth pace - emerging), category 3 - medium human development (usually country in the process of development) category 4 - low human development (poor countries) and category 5 - lowest human development (extreme poverty countries).

\section{Analysis}

To verify the normality of the sample, Kolgomorov-Smirnov test was used, showing absence of normality in all categories $(p<0.05)$. Moreover, Kruskal-Wallis $\mathrm{H}$ test (Table 3$)$ was applied for the different population 
categories, as well as it was calculated the effect size on the sample by epsilon squared (Kelley, 1935; Tomczak \& Tomczak, 2014); according to Cohen's (1988) interpretation (0-0.01 = no effect, 0.01-0.09= small; $0.09-0.25=$ intermediate; $>0.25=$ large). Likewise, post-hoc analysis was performed by MannWhitney $U$ test in (table 4) the groups where $p<0.05$ was obtained. Significance values were adjusted by Bonferroni correction for several tests. Also, Rosenthal's r (1991) was used to calculate the effect size on the sample and to find out whether these differences are large according to Cohen's (1988) interpretation (0-0.1 $=$ no effect, $0.1-0.3=$ small; 0.3-0.5 = intermediate; >0.5 = large).

In addition, odds ratios (OR) were calculated to determine the probability of participants being present in the database (table 5). In this way, ORs greater than 1 indicate that a given category would provide greater conditions for high swimming performance. On the other hand, ORs smaller than 1 showed that a given category implies less chances of having a higher swimming performance. Finally, when the ORs approach 1 , it indicates a lack of association between the variables.

All analyses were performed using software SPSS version 24 and Microsoft Excel 2016, maintaining the level of significance at $5 \%$.

\section{RESULTS}

Table 1. Frequencies and percentages of the number of cities and athletes (men and women) according to the index of the different HDI ranking (general, income, longevity and education). Created by the authors.

\section{HDI General}

\begin{tabular}{|c|c|c|c|c|c|c|c|c|}
\hline & \multicolumn{2}{|c|}{$\mathrm{N}^{0}$ City } & \multicolumn{2}{|c|}{$\operatorname{Men}(\hat{0})$} & \multicolumn{2}{|c|}{ Women $(q)$} & \multicolumn{2}{|c|}{ Athletes } \\
\hline $\begin{array}{c}\text { Category } \\
\text { HDI }\end{array}$ & $\mathrm{n}$ & $\%$ & $\mathrm{n}$ & $\%$ & $\mathrm{n}$ & $\%$ & $\mathrm{n}$ & $\%$ \\
\hline 1 & 34 & 17.7 & 2698 & 38.3 & 1946 & 37.2 & 4644 & 37.8 \\
\hline 2 & 148 & 77.1 & 4319 & 61.3 & 3271 & 62.5 & 7590 & 61.9 \\
\hline 3 & 10 & 5.2 & 24 & 0.6 & 13 & 0.3 & 37 & 0,3 \\
\hline Total & 192 & 100.0 & 7041 & 100.0 & 5230 & 100.0 & 12.271 & 100,0 \\
\hline \multicolumn{9}{|c|}{ HDI Income } \\
\hline 1 & 28 & 14.6 & 3632 & 51.6 & 2628 & 50.2 & 6260 & 51.0 \\
\hline 2 & 145 & 75.5 & 3282 & 46.6 & 2510 & 48.0 & 5792 & 47.2 \\
\hline 3 & 15 & 7.8 & 71 & 1.0 & 53 & 1.0 & 124 & 1.0 \\
\hline 4 & 4 & 2.1 & 56 & 0.8 & 39 & 0.8 & 95 & 0.8 \\
\hline Total & 192 & 100.0 & 7041 & 100.0 & 5230 & 100.0 & 12.271 & 100,0 \\
\hline \multicolumn{9}{|c|}{ HDI Longevity } \\
\hline 1 & 183 & 95.3 & 6926 & 98.4 & 5157 & 98.6 & 12083 & 98.5 \\
\hline 2 & 9 & 4.7 & 115 & 1.6 & 73 & 1.4 & 188 & 1.5 \\
\hline Total & 192 & 100.0 & 7041 & 100.0 & 5230 & 100.0 & 12.271 & 100,0 \\
\hline \multicolumn{9}{|c|}{ HDI Education } \\
\hline 1 & 5 & 2.6 & 363 & 5.2 & 236 & 4.5 & 599 & 4.9 \\
\hline 2 & 95 & 49.5 & 4482 & 63.7 & 3261 & 62.4 & 7743 & 63.1 \\
\hline 3 & 80 & 41.7 & 2120 & 30.1 & 1688 & 32.3 & 3808 & 31.0 \\
\hline 4 & 9 & 4.7 & 19 & 0.3 & 8 & 0.2 & 27 & 0.2 \\
\hline 5 & 3 & 1.6 & 57 & 0.8 & 37 & 0.7 & 94 & 0.8 \\
\hline Total & 192 & 100.0 & 7041 & 100.0 & 5230 & 100.0 & 12.271 & 100,0 \\
\hline
\end{tabular}


The cities were the athletes live were identified in the income and general $\mathrm{HDI}$ as of more than $70 \%$ in the category 2 of development, around $90 \%$ of them in the category 2 and 3 for education and $95 \%$ in the category 1 for longevity, being considered cities with high development (Table 1). As for the athletes it was identified that $90 \%$ are concentrated in cities of category 1 and 2 for the HDI general HDI development, income and longevity, whereas for the longevity around $63 \%$ are in the category 2 and $31 \%$ in the category 3 . The $\mathrm{HDI}$ categories 4 and 5 (low and lowest) represented less than $1 \%$ for the cities and athletes.

On the other hand, the were a positive correlation in the general HDI, income and education for both genders and for whole sample. Besides that, it was not found any correlation between HDI and longevity (Table 2).

Table 2. Correlations between the number of athletes and different indexes of various HDI categories (general, income, longevity and education). Created by the authors.

\begin{tabular}{|c|c|c|c|c|}
\hline \\
\hline & & $\operatorname{Men}\left(\bigcup^{\top}\right)$ & Women (q) & Athletes \\
\hline \multirow{2}{*}{ HDI General } & Rho $(\rho)$ & $.367^{\star \star}$ & $.317^{\star \star}$ & $.361^{* *}$ \\
\hline & $p$ &, 000 &, 000 & .000 \\
\hline \multirow{2}{*}{ HDI Income } & Rho $(\rho)$ & $.424^{* *}$ & $.389^{* *}$ & $.419^{* \star}$ \\
\hline & $p$ & .000 & .000 & .000 \\
\hline \multirow{2}{*}{ HDI Longevity } & Rho $(\rho)$ & .097 & .059 & .094 \\
\hline & $p$ & .180 & .416 & .197 \\
\hline \multirow{2}{*}{ HDI Education } & Rho $(\rho)$ & $.299^{* *}$ & $.256^{* *}$ & $.295^{\star *}$ \\
\hline & $p$ & .000 & .000 & .000 \\
\hline
\end{tabular}

${ }^{* *}$ The correlation is significant at the 0.01 level (bilateral).

Table 3. Kruskal-Wallis test determine the differences between the number of athletes (general, male and female) between the different HDI categories. Created by the authors.

\begin{tabular}{|c|c|c|c|c|c|c|c|c|c|}
\hline & \multicolumn{3}{|c|}{ Men $\left(\mathcal{O}^{\star}\right)$} & \multicolumn{3}{c|}{ Women $(+)$} & \multicolumn{3}{c|}{ Athletes } \\
\hline Category IDH & $H / U$ & $p$ & $e^{2}$ & $H / U$ & $p$ & $e^{2}$ & $H / U$ & $p$ & $e^{2}$ \\
\hline IDH General & 20.348 & $.000^{*}$ & .11 & 18.338 & $.000^{*}$ & .01 & 20.992 & $.000^{*}$ & .11 \\
\hline IDH Income & 31,409 & $.000^{*}$ & .16 & 29.607 & $.000^{*}$ & .16 & 32.218 & $.000^{*}$ & .17 \\
\hline IDH Longevity & 2,356 & .125 & - & 1.340 & .247 & - & 2.658 & .103 & - \\
\hline IDH Education & 22,286 & $.000^{*}$ & .12 & 18.285 & $.001^{*}$ & .10 & 22.434 & $.000^{*}$ & .12 \\
\hline
\end{tabular}

For the quantity of athletes (total, male and female), it was found significant differences between some HDI categories such as, income and education; not being present for the longevity. The same way that were found significant differences between all categories (Table 4), where the effect size was more notorious when the highest and lowest were compared in all analysed variables $(r>0.5)$.

Table 4. Post-hoc peer comparisons by the Mann Whitney $U$ test to determine the differences between the number of athletes (general, male and female) between the different HDI categories. Created by the authors.

\begin{tabular}{|c|c|c|c|c|c|c|c|c|c|}
\hline & \multicolumn{3}{|c|}{$\operatorname{Men}(\widehat{O})$} & \multicolumn{3}{|c|}{ Women ( } & \multicolumn{3}{|c|}{ Athletes } \\
\hline HDI General & $U$ & $p$ & $r$ & $U$ & $p$ & $r$ & $U$ & $p$ & $r$ \\
\hline 3-2 & 48.955 & $.020^{*}$ & .22 & 46.391 & $.031^{*}$ & .20 & 49.925 & $.017^{*}$ & 22 \\
\hline $3-1$ & 83.653 & $.000^{*}$ & .63 & 79.285 & $.000^{*}$ & 60 & 85.079 & $.000^{*}$ & 64 \\
\hline $2-1$ & 34.698 & $.003^{*}$ & .23 & 32.894 & $.005^{*}$ & 23 & 35.154 & $.003^{*}$ & 25 \\
\hline HDI Income & U & $p$ & $r$ & $U$ & $p$ & $r$ & $U$ & $p$ & $r$ \\
\hline $3-2$ & - & - & - & 40.385 & $.043^{*}$ & 21 & 41.664 & $.033^{*}$ & 22 \\
\hline
\end{tabular}




\begin{tabular}{|c|c|c|c|c|c|c|c|c|c|}
\hline $3-1$ & 90.198 & $.000^{*}$ & .78 & 89.994 & $.000^{*}$ & .78 & 92.951 & $.000^{*}$ & .80 \\
\hline $2-1$ & 51.375 & $.000^{*}$ & .34 & 49.609 & $.000^{*}$ & .33 & 51.287 & $.000^{*}$ & .34 \\
\hline HDI Education & $U$ & $p$ & $r$ & $U$ & $p$ & $r$ & $U$ & $p$ & $r$ \\
\hline $4-2$ & 70.261 & $.003^{*}$ & .36 & 64.764 & $.008^{*}$ & .33 & 71.096 & $.002^{*}$ & .36 \\
\hline $4-1$ & 104.467 & $.007^{*}$ & .90 & 110.611 & $.003^{*}$ & .95 & 111.133 & $.003^{*}$ & .96 \\
\hline $3-2$ & 25.057 & $.029^{*}$ & .23 & - & - & - & - & - & - \\
\hline
\end{tabular}

The OR's indicated that in the cities classified as category 1 (highest human development) the swimming athletes possess over 3 times the chances of becoming professional performance athletes according to the general $\mathrm{HDI}, 6$ times more the chances of the income HDI, almost 2 times more of the chances for education $\mathrm{HDI}$ and 3 times more of the chances for the longevity HDI (Table 5).

Table 5. Comparisons between athletes, population and $\mathrm{HDI}$, indicative of ORs. Created by the authors.

\begin{tabular}{ccccccc}
\hline Category HDI & \multicolumn{2}{c}{$\mathbf{N}^{0}$ City } & \multicolumn{2}{c}{$\mathbf{N}^{0}$ Athletes } & OR & (IC 95\%) \\
\hline General & $\mathrm{n}$ & $\%$ & $\mathrm{n}$ & $\%$ & & \\
\hline 1 & 34 & 17.7 & 4644 & 37.8 & $\mathbf{2 . 8 3}$ & $(1.95-4.11)$ \\
2 & 148 & 77.1 & 7590 & 61.9 & 0.48 & $(0.34-0.68)$ \\
3 & 10 & 5.2 & 37 & 0.3 & 0.06 & $(0.03-0.11)$ \\
\hline Total & 192 & 100.0 & 12271 & 100.0 & & \\
\hline
\end{tabular}

\begin{tabular}{ccccccc}
\hline Categorize HDI & \multicolumn{2}{c}{$\mathbf{N}^{\circ}$ City } & \multicolumn{2}{c}{$\mathbf{N}^{0}$ Athletes } & OR & (IC 95\%) \\
\hline Income & $\mathrm{n}$ & $\%$ & $\mathrm{n}$ & $\%$ & & \\
\hline 1 & 28 & 14.6 & 6260 & 51.0 & 6.10 & $(4.08-9.12)$ \\
2 & 145 & 75.5 & 5792 & 47.2 & 0.29 & $(0.21-0.40)$ \\
3 & 15 & 7.8 & 124 & 1.0 & 0.12 & $(0.07-0.21)$ \\
4 & 4 & 2.1 & 95 & 0.8 & 0.38 & $(0.13-1.01)$ \\
\hline Total & 192 & 100.0 & 12271 & 100.0 & & \\
\hline
\end{tabular}

\begin{tabular}{ccccccc}
\hline Category HDI & \multicolumn{2}{c}{$\mathbf{N}^{\mathbf{0}}$ City } & \multicolumn{2}{c}{$\mathbf{N}^{\mathbf{0}}$ Athletes } & OR & (IC 95\%) \\
\hline Education & $\mathrm{n}$ & $\%$ & $\mathrm{n}$ & $\%$ & & \\
\hline 1 & 5 & 2.6 & 599 & 4.9 & 1.92 & $(0.79-4.68)$ \\
2 & 95 & 49.5 & 7743 & 63.1 & 1.75 & $(1.31-2.32)$ \\
3 & 80 & 41.7 & 3808 & 31.0 & 0.63 & $(0.47-0.84)$ \\
4 & 9 & 4.7 & 27 & 0.2 & 0.04 & $(0.02-0.10)$ \\
5 & 3 & 1.6 & 94 & 0.8 & 0.49 & $(0.15-1.55)$ \\
\hline Total & 192 & 100.0 & 12271 & 100.0 & & \\
\hline Category HDI & \multicolumn{7}{c}{$\mathbf{N}^{0}$ City } & \multicolumn{7}{c}{$\mathbf{N}^{\mathbf{0}}$ Athletes } & OR & $($ IC 95\%) \\
\hline Longevity & $\mathrm{n}$ & $\%$ & $\mathrm{n}$ & $\%$ & & \\
\hline 1 & 183 & 95.3 & 12083 & 98.5 & 3.16 & $(1.59-6.28)$ \\
2 & 9 & 4.7 & 188 & 1.5 & 0.32 & $(0.16-0.63)$ \\
\hline Total & 192 & 100.0 & 12271 & 100.0 & & \\
\hline
\end{tabular}




\section{DISCUSSION}

The objective of this study is to identify the correlation between the HDI of Brazilian cities and the performance of swimming athletes. Therefore, it was found that the HDI can be utilized as an epidemiological tool in the identification of athletes with chances of reaching a professional performance.

In contrast with the studies of Dumith et al. (2011) and Dummied et al. (2018) that identified $20 \%$ of the world population as being physically inactive, and concentrated in its majority in countries with high HDI, the present study analysed athletes currently in the swimming ranks, therefore, all physically active. The authors did not identify the correlation of the remaining $80 \%$ that could also be associated to the countries with a higher HDI.

The most recent studies of Chacon-Araya, Villarreal-Angeles \& Moncada-Jimenez (2018) and Santos et al. (2019) follow our findings, as they evaluated groups of competitive athletes, as well as identifying bigger chances on countries with high HDU for athletes. The fact that the income HDI indicated six times more chances of having performance swimming athletes confirm the studies of Houlihan \& Green (2005), Coakley (2015) and De Bosscher et al. (2015) when associating the sportive success in competitions of high competitive levels with financial investments of athletes, technical teams and infrastructure. The positive indications can be confronted against the infrastructure available in Brazilian cities and sport incentive programs.

The current research was limited to analyse swimming Brazilian athletes, which could restrict the results by the specific modality, making it necessary to confront with interventions in other sport modalities, as well as data from other countries. In addition, another limitation was the low literature available regarding the influence of $\mathrm{HDI}$ in the sportive performance, reason why it recommended a higher number of researches about this subject.

\section{CONCLUSIONS}

We conclude that the Brazilian cities with high general HDI as well as for income and education, provided higher chances for competitive level swimming athletes.

In the same line of thought, populated cities with high HDI tend to develop government sports incentive programs, have more private sports promoting institutions and can select high-performance athletes from society.

\section{FINANCING}

This research was financed by the Brazilian Ministry of Sport (ME) through a project called Sport Intelligence, conducted by the Federal University of Paraná (UFPR), as well as researcher in the form of international joint supervision coming from Murcia (Spain) (Extract of cooperation term 72/2018 - Case 23075.023034 \201831).

\section{REFERENCES}

Baker, J. \& Logan, A. J. (2007). Developmental contexts and sporting success: Birth date and birthplace effects in national hockey league draftees 2000-2005. British Journal of Sports Medicine, 41(8), 5157. https://doi.org/10.1136/bjsm.2006.033977 
Baker, J., Schorer, J., Cobley, S., Schimmer, G., \& Wattie, N. (2009). Circumstantial development and athletic excellence: The role of date of birth and birthplace. European Journal of Sport Science, 9, 329-339. https://doi.org/10.1080/17461390902933812

Bruner, M. W., Macdonald, D. J., Pickett, W., \& Côté J. (2011). Examination of birth- place and birthdate in World Junior ice hockey players. Journal of Sport Science. 29(12), 1337-44. https://doi.org/10.1080/02640414.2011.597419

Bruner, M. W., Macdonald, D. J., Pickett, W., \& Côté J. (2011). Examination of birth- place and birthdate in World Junior ice hockey players. Journal of Sport Science. 29(12), 1337-44. https://doi.org/10.1080/02640414.2011.597419

Caetano, C. I.; Sentone, R. G.; López-Gil, J. F.; Caetano, H. B. S.; Cavichiolli (2020). Influence of population size and density on sports performance of Brazilian artistic gymanstics. Retos: Nuevas tendências em Educacion Física, Deporte y Recreación, 38, 66-70.

Canan, F.; Santos, L. L. S. R.; Starepravo, F. A. Panorama geral sobre políticas e esporte no Brasil. Caderno de Educação Física e Esporte, v. 15, n. 1, p. 15-27, 2017.

Chacón-Araya, Y.; Villarreal-Ángeles, M.; Moncada-Jiménez, J. (2018). The association between socioeconomic indicators and the cantonal sports perfomance in the national sport games Costa Rica 2016. Journal of Physical Education and Sport, v. 18, n. 3, p. 1549-1554. http://dx.doi.org/10.7752/jpes.2018.03229

Coakley, J. (2015). Sport in Society. Issues and Controversies. $11^{a}$ edição. McGraw-Hill Education. New York.

Cohen, J. (1988). Statistical power analysis for the behavioral science. Nova York: Academic Press.

Costa, I. T.; Cardoso, F. S. L.; Garganta, J. (2013). O Índice de Desenvolvimento Humano e a Data de Nascimento podem condicionar a ascensão de jogadores de Futebol ao alto nível de rendimento? Motriz, v. 19, n. 1, p. 34-45, jan.-mar., 2013. https://doi.org/10.1590/s1980-65742013000100004

Côté, J., MacDonald, D. J., Baker, J., \& Abernethy, B. (2006). When "where" is more important than "when": Birthplace and birthdate effects on the achievement of sporting expertise. Journal of Sports Sciences, 24(10), 1065-73. https://doi.org/10.1080/02640410500432490

De Bosscher, V.; Shibil, S.; Westerbeek, H.; Botteburg, M. V. Sucessful Elite Sport Policies. An international comparison of the Sport Policy factors leading to international sporting sucess (SPLISS 2.0) in 15 nations. Maidenhead: Mayer e Mayer Sport, UK. 2015. https://doi.org/10.4324/9781315753461-9

Dumith SC., Hallal PC, Reis RS, Kohl HW. (2011). Worldwide prevalence of physical inactivity and its association with human development index in 76 countries. Preventive medicine, v. 53, n. 1-2, p. 2428. https://doi.org/10.1016/i.ypmed.2011.02.017

Dumuid D, Maher C, Lewis LK, Stanford TE, Martín Fernández JA, Ratcliffe J, et al. (2018). Human development index, children's health-related quality of life and movement behaviors: a compositional data analysis. Quality of Life Research, v. 27, v. 6, p. 1473-82. https://doi.org/10.1007/s11136-018$\underline{1791-x}$

Faber, I. R., Bustin, P. M. J., Oosterveld, F. G. J., Elferink-Gemser, M. T., \& Nijhuis-Van der Sanden, M. W. (2015). Assessing personal talent determinants in young racquet sport players: a systematic review. Journal of Sports Sciences, 34(5), 395-410. https://doi.org/10.1080/02640414.2015.1061201

Farinola, M. G., Tuñón, I., Laiño, F., Marchesich, M., \& Rodríguez, M. P. (2018). Perfil socioeducativo y económico de deportistas adolescentes de élite argentinos. Retos, 34, 172-176. Retrieved from: https://recyt.fecyt.es/index.php/retos/article/view/60072/38236 
Finnegan, L., Richardson, B. D., Littlewood, M. \& Mcardlea, J. (2016). The influence of date and place of birth on youth player selection to a National Football Association elite development programme. Science and Medicine in Football, 1(1), 30-9. https://doi.org/10.1080/02640414.2016.1254807

Finnegan, L., Richardson, B. D., Littlewood, M. \& Mcardlea, J. (2016). The influence of date and place of birth on youth player selection to a National Football Association elite development programme. Science and Medicine in Football, 1(1), 30-9. https://doi.org/10.1080/02640414.2016.1254807

Fraser-Thomas, J., Côté, J., \& MacDonald, D. (2010). Community size in youth sport settings: Examining developmental assets and sport withdrawal. PHENex Journal, 2(2). Retrieved from: http://ojs.acadiau.ca/index.php/phenex/article/view/8/1172

Gomez-Lopez, M., Sanchez, S. A., Gallegos, A. G., Rios, L. J. C. (2017). Relative age effect in handball players of Murcia: influence of sex and category of game. Journal of Human Sport \& Exercise, v. 12, n. 3. https://doi:10.14198//hse.2017.123.01

González, S. A. et al. (2018). Resport card grades on the physical activity of children and youth from 10 countries with high human development index: Global Matrix 3.0. Journal of Physical Activity and Health, v. 15, suppl. 2, p. S284-297. https://doi.org/10.1123/jpah.2018-0391

Hancock, D. J., Adler, A. L., \& Côté, J. (2013). A proposed theoretical model to explain relative age effects in sport. European Journal of Sport Science, 13(6), 630-7. https://doi.org/10.1080/17461391.2013.775352

Hancock, D. J., Coutinho, P., Côté, J., \& Mesquita, I. (2017). Influences of population size and density on birthplace effects. Journal of Sports Sciences, 36(1), 33-38. https://doi.org/10.1080/02640414.2016.1276614

Houlihan, B.; Green, M. Elite Sport Development Policy Learning and Political Priorities. London: Routledge. 2005.

Lidor, R., Arnon, M., Maayan, Z., Gershon, T., \& Côté, J. (2014). Relative age effect and birthplace effect in Division 1 female ballgame players-The relevance of sport-specific factors. International Journal of Sport and Exercise Psychology, 12(1), 19-33. https://doi.org/10.1080/1612197X.2012.756232

McGowin D. (2010). Sports, geography of. En B. Warf (Ed.), Encyclopaedia of geography (pp. 2681-3). Thousand Oaks, EE.UU:: Sage.

Ortiz, E. M., Colomina, R. A. (2019). Regression analysis model applied to age-group swimmers: 50m race component time analysis. Journal of Human Sport \& Exercise, v. 14, n. 2. https://doi.org/10.14198/ihse.2019.142.05

PNUD. (2019) Programas das Nações Unidas para o Desenvolvimento. Accessed at: https://www.br.undp.org/content/brazil/pt/home.html. Accessed at: 14 de outubro de 2019.

Rossing N. N., Nielsen A. B., Elbe A. M, \& Karbing, D. S. (2016). The role of community in the development of elite handball and football players in Denmark. European Journal of Sport Science. 16(2), 237-45. https://doi.org/10.1080/17461391.2015.1009492

Santos, P. A. et al. (2019). Human Development Index and the frequency of nations in athletics World Ranking. Sport Sciences for Health, v. 15, v. 2, p. 393-398. https://doi.org/10.1007/s11332-01900529-1

The United Nations Development Programme (2018). Human Development Indices and Indicators, 2018 Statistical Update. New York: The United Nations Develepment Programme; 2018 [accessed 2018 nov 10]. Accessed

at: http://hdr.undp.org/sites/default/files/2018_human_development_statistical_update.pdf

Kelley, T. L. (1935). An Unbiased Correlation Ratio Measure. Proceedings of the National Academy of Sciences of the United States of America, 21(9), 554-559. Retrieved from: https://www.ncbi.nlm.nih.gov/pmc/articles/PMC1076656/pdf/pnas01761-0040.pdf 
Tomczak, M., \& Tomczak, E. (2014). The need to report effect size estimates revisited. An overview of some recommended measures of effect size. TRENDS in Sport Sciences, 1(21), 19-25. Retrieved from: http://www.tss.awf.poznan.pl/files/3_Trends_Vol21_2014_no1_20.pdf

Rosenthal, R. (1991). Meta-analytic procedures for social research (Rev. ed). Newbury Park (California), EUA: Sage Publications.

\section{(c) $(1) \Theta$}

This work is licensed under a Attribution-NonCommercial-NoDerivatives 4.0 International (CC BY-NC-ND 4.0). 